\title{
The Effect of Using Small Group Discussions Through Zoom Breakout Room to Increase the Frequency of Individual Speaking Participation in the Speaking Courses
}

\author{
Lulu Zahrotun Nisa, Taqiya Nabila Prameswari, Yayah Izzah Alawiyah* \\ English Education Department, Universitas Islam Negeri Syarif Hidayatullah Jakarta, 15412, Indonesia \\ "Corresponding author: yayah.izzah19@mhs.uinjkt.ac.id
}

Received: 6 November 2021; Accepted: 16 December 2021; Published: 27 December 2021

\begin{abstract}
The purpose of this study is to determine whether the small group discussion method via breakout room zoom may boost student individual engagement in order for them to be more active and confident in learning speaking. This research study used a qualitative method with applied video analysis and questioners' perceptions of students as instruments. The findings found 17 active participants in the observation speaking class and 35 participants preferred small group discussions using the breakout room zoom application, with the majority preferring small group discussions because it helped them to be more active and confident. This method can also boost their confidence for more active participation for individual speaking in class, and they believe that small group discussions via breakout room zoom are the most effective way to deal with a pandemic.
\end{abstract}

Keywords: Speaking, Small Group Discussion, Breakout room Zoom application

\section{INTRODUCTION}

Speaking is an active skill that has to be mastered to communicate with other people, but there are some obstacles to learn especially not native speaker countries such as Indonesia. People just talk because it is such an important part of our daily life that sometimes we forget how hard we worked to achieve it until we have to know and understand how to do it in a foreign language (Thornbury, 2005). A very strong effort sometimes makes you more nervous and afraid to speak a foreign language even though speaking is a common thing to do. Based on the article from Suryadi (2020), the challenge in teaching speaking English is students lacking confidence in speaking their ideas in front of the class because they were concerned that their classmates would be funny at their mistakes. The other research from Tasmia (2019) says students have difficulty speaking such as shyness, grammatical structures, vocabulary and meaning, pronunciation, lack of self-confidence, fear of making mistakes, and nervousness are all issues. From these two kinds of research, many students have problem in the anxiety and nervousness when speaking English. Speaking anxiety aspects in English Foreign Language caused by self-prediction of fear, unreasonable faith, oversensitivity to threat, anxiety awareness, and students' lack of confidence in speaking English (Isnaini, 2018). Because of these aspects, it is important to create a supportive learning environment by encouraging peer support in the classroom, be sensitive when assigning students into groups, provide opportunities for students to speak English outside of class, and make the classroom environment non-threatening (Arifin, 2017).

However, nowadays, a learning process is using various applications based online because of the Covid-19 pandemic. Students study from home and teachers work from home limited by distance. It can make more gaps in the learning process and make an adverse impact on the study. Learning speaking in online courses did not help students improve their speaking abilities because some of the 
anxiety comes from the online connection, accessible devices, students' data, and the desire of some students to express their ideas in offline class (Fitriani et al., 2020). According to Baron et al. (2020), suggested in the articles that future studies should dedicate more resources to observing the use of online learning media in order to implement online learning media in integrated English learning skills to maximize the level of effectiveness on learning outcomes.

The most important practice is active learning (Johnson, 2020) and to make active learning and meaningful lessons, teachers need to make interesting activities to engage students' motivation. In the classroom, there are many speaking activities, such as screenplay acting, interaction games, and discussion activities, such as events staged by the entire group that range from formal to informal small group discussions (Harmer, 2007). Small group discussions can be used as a tool for collaborative learning and as a motivator for improving oral communication skills (Larasati, 2018). It helps students develop their interpersonal skills and confidence by making them aware of different perspectives on the material, encouraging personal engagement in the learning process, and instilling trust with other people (Daely et al., 2019). Not only useful for confidence, but they also could practice their speaking skills freely and regularly (Ratih et al., 2016). Many results from research approved that small group discussion can make speaking skills students improve. Five aspects of speaking skills such as pronunciation, grammar, vocabulary, fluency, and content improve after using small group discussion. It encourages them to speak freely, express themselves, and actively in class activities (Daely et al., 2019). Small group discussion is working on a group to engage students more actively when learning the lesson and improve speaking skills.

Zoom application is usually used as a synchronous meeting included in learning. Zoom is highly recommended for online learning because it gives many great offers from the tool like breakout room, whiteboard, and more stable network (Risma, 2021). One of the tools from zoom that can be used for active group work as well as in the classroom is the breakout room. Separate synchronous sessions like Zoom breakout room is a feature that allows students to privately talk with each other, screen-share, and share files (Bailey et al., 2021). The usage of breakout rooms in the zoom application was made for each group that contained several students, and students were added to those rooms before the start of the activity of study (Vollbrecht et al., 2020). A breakout room may help students to learn actively by group work like in the offline classroom.

The article wants to develop research on the use of small group discussions which have had many positive results in developing speaking participation, but with something that has not been researched before, go online using the Zoom breakout room. Besides that, based on Baron et al. (2020) who said that more research is needed on English learning skills online. Therefore, to find out whether or not small group discussion in breakout room zoom effect to speaking participation in speaking class, qualitative research was conducted to answering the research question, so the purpose of this study is to find effective online learning ways to increase speaking participation in speaking classes so that students practice more during online classes.

\section{METHOD}

The research was taking place to the Students of English Education, Faculty of Tarbiyah and Educational Sciences at Syarif Hidayatullah Jakarta who have taken Speaking 4 courses in 2021. In this research, the researchers used a qualitative research method. The population of the research was the $5^{\text {th }}$ semester students of English Education which consist of 4 classes. The first method is observation to the speaking class that consists of 17 active participations by students in four classes. The second method is questionnaire and distributed to the students that pass the speaking class in 2021 which consist of 35 participants that filled out the questionnaires.

The emphasis for this study was on finding out the effect of using small group discussion through zoom breakout room in increasing the frequency of individual speaking participation. The researchers used observation class when the participant discussed arguing for and arguing against in the debate. Because the course has been completed in semester 4 , the observation is done by observing video recordings when practice debate in the speaking 4 class. Four classes were observed learning using small group discussion in the Zoom breakout room before speaking in the main session 
and having the same lecturer. Each class gets the opportunity to have 4 speakers convey their ideas about the topic of debate, gender equality between men and women.

Further step to know more about the student's perspective that made them want to participate in the speaking class after they used small group discussion in the Zoom breakout room. The researchers used questionnaires that have 14 positive statements which have a choice of answers with a likert scale. A Likert scale suggests that the power of an attitude is straightforward; that is strongly agree, agree, undecided, disagree, strongly disagree; and also that attitudes can be evaluated. The result questionnaires were filled out by 35 students that had even a small group discussion through the Zoom breakout rooms in speaking online class which is on the 4th semester previously.

\section{RESULT AND DISCUSSION}

The result from an observation video recording of speaking 4 class $A$ (Table 1), most of the speakers active speaking and fast responses. The first speaker, student 1 volunteered to argue for the topic with confidence. The second speaker is student 2 who volunteered to argue against student 1's statements about the topic with speak fluently and confidently. After that, student 1 wants to argue again but the lecturer wants other students to try, especially females. After a long time, the female speaker, student 3 gave her ideas to support student 1's idea, but she seemed nervous because she stammered and gave some ideas. The last speaker is student 4 , who wants to try to speak as a third speaker, but he is in the wrong place because of his ideas for arguing against student 1's ideas, so he speaks as a fourth speaker. He speaks a little stammered and ideas but sounds confident because ready to answer. From A class speakers, no one opened the camera and was quite active speaking in the main session.

Table 1. Observation video recording Class A (Arguing for or arguing against/debate)

\begin{tabular}{|c|c|c|c|c|c|c|}
\hline No. & Name & $\begin{array}{c}\text { Volunteer/ be } \\
\text { indicated }\end{array}$ & $\begin{array}{c}\text { Ask/ } \\
\text { Answer }\end{array}$ & $\begin{array}{c}\text { Fast/ long time } \\
\text { to speaking }\end{array}$ & $\begin{array}{l}\text { Nervous/ } \\
\text { confident }\end{array}$ & Note \\
\hline 1 & Student 1 & Volunteer & Answer & Long time & Confident & $\begin{array}{l}\text { It took } 2 \text { times to be } \\
\text { called by the teacher, } \\
\text { want to try again, the } \\
\text { answer is long, and off } \\
\text { camera. }\end{array}$ \\
\hline 2 & Student 2 & Volunteer & Answer & Fast & Confident & $\begin{array}{l}\text { It only takes } 1 \text { time, the } \\
\text { answer is long, and off } \\
\text { camera. }\end{array}$ \\
\hline 3 & Student 3 & Be indicated & Answer & Long time & Nervous & $\begin{array}{l}\text { It took } 3 \text { times to be } \\
\text { called, especially } \\
\text { female, the answer is } \\
\text { short, and off camera. }\end{array}$ \\
\hline 4 & Student 4 & Volunteer & Answer & Long time & Confident & $\begin{array}{l}\text { Previously wanted to } \\
\text { try but in the wrong } \\
\text { place so try it now, and } \\
\text { off camera. }\end{array}$ \\
\hline
\end{tabular}

In speaking 4 class B (Table 2), many participants volunteered to speak in the main session but there is some required response time to answer. The first speaker, student 5 volunteered to speak with an open camera and many ideas, so seems confident. The second is student 6 volunteered but needed 2 times called, but unfortunately, she is in the wrong place to argue because she supports student 5 's statement. The third speaker was still in the wrong place because support the first speaker, opened the camera, stammered, and did not have many ideas, but she volunteered even though it takes a long time when called by the lecturer. The fourth speaker is student 8 who volunteered with a confident and appropriate place to argue against the first speaker. The last speaker is student 9 that is indicated by the lecturer, who opens the camera, stammered, and does not have many ideas to support the first speaker. The class B participants are too many participants because there is a 
misplaced arguing against into arguing for, but quite confident and many participants speaking in the main session.

Table 2. Observation video recording Class B (Arguing for or arguing against/debate)

\begin{tabular}{|c|c|c|c|c|c|c|}
\hline No. & Name & $\begin{array}{l}\text { Volunteer/ } \\
\text { be indicated }\end{array}$ & $\begin{array}{c}\text { Ask/ } \\
\text { Answer }\end{array}$ & $\begin{array}{l}\text { Fast/ long time } \\
\text { to speaking }\end{array}$ & $\begin{array}{l}\text { Nervous/ } \\
\text { confident }\end{array}$ & Note \\
\hline 1 & Student 5 & Volunteer & Answer & Fast & Confident & $\begin{array}{l}\text { Open camera, the answer is } \\
\text { long. }\end{array}$ \\
\hline 2 & Student 6 & Volunteer & Answer & Long time & Confident & $\begin{array}{l}\text { It took } 2 \text { times to be called } \\
\text { and invited, the statement } \\
\text { was the same as student } 5 \text {, } \\
\text { short and clear, off camera, } \\
\text { and wrong place to argue. }\end{array}$ \\
\hline 3 & Student 7 & Volunteer & Answer & Long time & Nervous & $\begin{array}{l}\text { It took many times to be } \\
\text { invited } 4 \text { times, the } \\
\text { statement was the same as } \\
\text { student } 5 \text {, wrong place to } \\
\text { argue, short and clear, and } \\
\text { open camera. }\end{array}$ \\
\hline 4 & Student 8 & Volunteer & Answer & Fast & Confident & $\begin{array}{l}\text { Need 1-2 times to be called, } \\
\text { different and disagree with } \\
\text { student } 5 \text { 's statement, short } \\
\text { but straight to the point, and } \\
\text { off camera. }\end{array}$ \\
\hline 5 & Student 9 & Be indicated & Answer & Long time & Nervous & $\begin{array}{l}\text { It takes many times to be } \\
\text { invited } 3 \text { times, the } \\
\text { statement is the same as } \\
\text { student } 5 \text {, short and to the } \\
\text { point, and open camera. }\end{array}$ \\
\hline
\end{tabular}

The speaking 4 class $C$ (Table 3), all of the speakers volunteered to convey their ideas, but two of four speakers need more times to answer. The first speaker is student 10, volunteered after two times calling with the open camera, and seems nervous because often saw her notes. The second speaker quickly volunteered to argue against the first speaker, many ideas, sounded confident, but did not activate the camera. The third speaker is student 12 , who volunteered after three times being called especially man. He gave a short answer, did not activate the camera, but sounded confident because speaking fluently. The last speaker is student 13 , fast volunteers, clear ideas to support student 10 , but not activate the camera. Overall speaking participants in class $C$ are active however need some times to answer and volunteer as speakers.

Table 3. Observation video recording Class C (Arguing for or arguing against/debate)

\begin{tabular}{|c|c|c|c|c|c|c|}
\hline No. & Name & $\begin{array}{c}\text { Volunteer/ be } \\
\text { indicated }\end{array}$ & $\begin{array}{c}\text { Ask/ } \\
\text { Answer }\end{array}$ & $\begin{array}{l}\text { Fast/ long time } \\
\text { to speaking }\end{array}$ & $\begin{array}{l}\text { Nervous/ } \\
\text { confident }\end{array}$ & Note \\
\hline 1 & Student 10 & Volunteer & Answer & Long time & Nervous & $\begin{array}{l}\text { It took } 2 \text { calls, looked } \\
\text { at the notes too often, } \\
\text { the answer was short, } \\
\text { and on camera. }\end{array}$ \\
\hline 2 & Student 11 & Volunteer & Answer & Fast & Confident & $\begin{array}{l}\text { The answer is long and } \\
\text { responds to student 10' } \\
\text { opinion but off camera. }\end{array}$ \\
\hline 3 & Student 12 & Volunteer & Answer & Long time & Confident & $\begin{array}{l}\text { Need to be called many } \\
\text { times } 3 \text { times especially } \\
\text { male, off camera, and } \\
\text { short answer. }\end{array}$ \\
\hline 4 & Student 13 & Volunteer & Answer & Fast & Confident & $\begin{array}{l}\text { Smooth, agree with } \\
\text { student } 10 \text { 's statement, } \\
\text { but off camera. }\end{array}$ \\
\hline
\end{tabular}


The last class has two volunteers and two participants that are chosen by the lecturer (Table 4). The first speaker was student 14 who volunteered fast, sounded confident, but did not open the camera. The second speaker needed 2 times to call but volunteered with confidence. The third and fourth speaker is indicated by the lecturer but sounds confident to answer. A half speaker needs time to answer, and half other speakers are also indicated by the lecturer.

Table 4. Observation video recording Class D (Arguing for or arguing against/debate)

\begin{tabular}{lclllll}
\hline No. & Name & $\begin{array}{c}\text { Volunteer/ be } \\
\text { indicated }\end{array}$ & $\begin{array}{c}\text { Ask/ } \\
\text { Answer }\end{array}$ & $\begin{array}{c}\text { Fast/ long time } \\
\text { to speaking }\end{array}$ & $\begin{array}{c}\text { Nervous/ } \\
\text { confident }\end{array}$ & Note \\
\hline 1 & Student 14 & Volunteer & Answer & Fast & Confident & $\begin{array}{l}\text { Short answer, want to } \\
\text { try again, off camera. }\end{array}$ \\
2 & Student 15 & Volunteer & Answer & Long time & Confident & $\begin{array}{l}\text { The answer is short and } \\
\text { it takes 2 times to be } \\
\text { called, off camera. }\end{array}$ \\
3 & Student 16 & Be indicated & Answer & Long time & Confident & $\begin{array}{l}\text { Need 3 times to be } \\
\text { called, and off camera } \\
\text { Short answer, and off } \\
\text { camera. }\end{array}$ \\
\hline
\end{tabular}

Besides the video analysis, the researchers also have Students' perception through used questionnaires as the instrument that would support our research or to support the effect that shows from the video analysis. Table 5 is the result of the answers questionnaires, after the researchers collected the data by questionnaires that were filled out by 35 students, they even had a small group discussion through the Zoom breakout rooms in speaking online class which was on the 4th semester previously.

Based on Table 5, there are 16 questions that determine the efficiency, how students can make their time efficient with their group. confidence, how students can make it a place to improve their confidence and activeness, how students' way to be more active in small group discussion. Because the purpose of these questionnaires is to know students' perception about this small group discussion, they agree or not with this method. So, from this table of students' perception, the result of most students' perception that $54 \%$ respondents are said to agree with this method, which can make them more efficient, confident and active in their individual speaking.

Based on students' perception, the result shows that 21 people of the respondents they said agree with small group discussion because using a breakout room makes their time more efficient to practice speaking, 23 people of the respondents said agree because they can prepare and practice in advance in the breakout room session for speaking in the main session, 16 people of the respondents they said Strongly agree that they can practice speaking together in the breakout room in turns, and 18 people of the respondents they said agree that they can discuss with my partner confidently in the breakout room session.

\section{DISCUSSION}

From the conclusion of the video recording observation, most of the students quite participate in the speaking in the main session after using small group discussion in the Zoom breakout room. In line with Rogers' research, the use of small groups is quite influential (McDaniels et al., 2016) in increasing student participation in class. It can be seen that they volunteered to answer even a fast response to the question. However, some students responded to the lecturer slowly, stammered, off camera while give the argument, or did not even answer the lecturer questions because of shame (Suryadi, 2020) and fear of being wrong (Isnaini, 2018). There is also a misunderstanding in class B regarding the rules in arguing against, but there are still students who want to try to express their opinion in the main session, so that the video recording observation can approve using small group discussion increasing student participation in class.

Second thing from video recording to people that participated in the main session to speak their ideas in a good way. From 17 students that participated in the main session after using small 
group discussion in the Zoom breakout room, there are 13 students that are confidence to give their ideas. It means that they were quite confidence when speaking in the main session because previously there had been preparations with their friends in the breakout room. Feedback from teachers or friends, as well as how it is communicated, affects the students' speaking performance, so it can be an important factor in determining whether or not a speaker's performance is successful (Opandi, 2019). In addition to increasing participation, the use of small group discussions in the Zoom breakout room also increases students' confidence when speaking in the main session.

Table 5. Students' perception

\begin{tabular}{|c|c|c|c|c|c|c|}
\hline NO. & QUESTION & $S A$ & A & $\mathrm{N}$ & D & SD \\
\hline 1 & $\begin{array}{l}\text { The use of a breakout room makes time } \\
\text { more efficient to practice speaking with a } \\
\text { small group. }\end{array}$ & 12 & 21 & 2 & 0 & 0 \\
\hline 2 & $\begin{array}{l}\text { I can prepare and practice in advance in } \\
\text { the breakout room session for speaking in } \\
\text { the main session. }\end{array}$ & 12 & 23 & 0 & 0 & 0 \\
\hline 3 & $\begin{array}{l}\text { Practice speaking together in the breakout } \\
\text { room in turns. }\end{array}$ & 16 & 14 & 4 & 1 & 0 \\
\hline 4 & $\begin{array}{l}\text { I can discuss with my partner confidently in } \\
\text { the breakout room session. }\end{array}$ & 12 & 18 & 4 & 1 & 0 \\
\hline 5 & $\begin{array}{l}\text { Everyone has the opportunity to practice } \\
\text { in the breakout room. }\end{array}$ & 14 & 16 & 5 & 0 & 0 \\
\hline 6 & $\begin{array}{l}\text { Get a peer review about speaking from a } \\
\text { group of friends. }\end{array}$ & 5 & 13 & 16 & 1 & 0 \\
\hline 7 & $\begin{array}{l}\text { Every student in the breakout room gets a } \\
\text { peer review from their friend. }\end{array}$ & 5 & 13 & 16 & 1 & 0 \\
\hline 8 & $\begin{array}{l}\text { Peer review from my friend in the } \\
\text { breakout room is useful when appearing in } \\
\text { the main session. }\end{array}$ & 5 & 22 & 8 & 0 & 0 \\
\hline 9 & $\begin{array}{l}\text { There are not many technical problems } \\
\text { when using the breakout room, so the } \\
\text { small group discussion goes smoothly. }\end{array}$ & 8 & 15 & 10 & 2 & 0 \\
\hline 10 & $\begin{array}{l}\text { Fluent in speaking during the main session } \\
\text { after practicing together in the breakout } \\
\text { room. }\end{array}$ & 5 & 16 & 13 & 1 & 0 \\
\hline 11 & $\begin{array}{l}\text { After using the breakout room, a lot of } \\
\text { active participation in speaking } 4 \text {. }\end{array}$ & 2 & 20 & 12 & 1 & 0 \\
\hline 12 & $\begin{array}{l}\text { My confidence increases when speaking in } \\
\text { the main session. }\end{array}$ & 2 & 20 & 11 & 2 & 0 \\
\hline 13 & $\begin{array}{l}\text { Small group discussion through the } \\
\text { Breakout room in zoom, can increase the } \\
\text { confidence to speak. }\end{array}$ & 7 & 25 & 1 & 2 & 0 \\
\hline 14 & $\begin{array}{l}\text { Small group discussion through Breakout } \\
\text { room in zoom make it easier for me to } \\
\text { improve speaking skills in speaking class } 4 \text {. }\end{array}$ & 2 & 30 & 3 & 0 & 0 \\
\hline & TOTAL & $\begin{array}{c}107 \\
(22 \%)\end{array}$ & $\begin{array}{c}266 \\
(54 \%)\end{array}$ & $\begin{array}{c}105 \\
(12 \%)\end{array}$ & $\begin{array}{c}12 \\
(2 \%)\end{array}$ & $\begin{array}{c}0 \\
(0 \%)\end{array}$ \\
\hline
\end{tabular}

According to the findings regarding students' perceptions of small group discussion, most students agreed with the small group Discussion method via breakout rooms on the Zoom application. They have seen small group discussion as beneficial because it taught them to be more active, more confident to solve problems collaboratively, to accept responsibility, and to negotiate with their peers. This confirms Silaban (2016) study's findings reveal that students have a good 
perspective about small group discussion in terms of how they gained, how much they heard, and how much they enjoyed learning in small group discussion.

According to the findings regarding the effectiveness of small group discussion, the majority of students believed that small group discussion is an effective learning technique. They believed that small group discussions were the most effective way to facilitate task completion and shorten the time required to complete assignments. This support from (Bohari, 2020) that was taught through small group discussion aided the students' speaking skills because they learned together and did not find it difficult to learn and practicing in front of their friends. It can also boost their confidence for more active speaking in class.

We can conclude that average the total 'strongly disagree' replies were $0 \%$, 'disagree' was $2 \%$, 'neutral' was $12 \%$, 'agree' was $54 \%$, and 'strongly agree' was $22 \%$, according to the participants' comprehensive responses to the entire questionnaire. As a result, it may be inferred that students' perceptions of group work in English classes are favorable. Table 2. Students' perception questionnaires illustrate this.

\section{CONCLUSION}

This small group discussion method is powerful in building interactive communication between students. Students can exchange ideas and opinions about learning discussions in small group discussions so that students can be more confident in their speaking skills. Not only exchanging ideas and opinions, but small group discussions can produce different knowledge, experiences, and talents that are shared by each student in the small group.

From this study, it can be concluded that the learning method using the Zoom breakout room is effective in increasing students' participation to speak in a speaking course. The effect was seen in the observation video, most of them dared to volunteer to speak in the main session after conducting a small discussion. This means that the learning media using small group discussion through zoom breakout rooms used by lecturers and students in learning speaking 4 has succeeded in increasing students' participation and confidence in expressing opinions and speaking in speaking class. It also can be seen from the questionnaires about students' perspective, the students agreed to use small group discussion in the Zoom breakout room and made effective learning for speaking class.

Future research could duplicate this study by involving more people in a larger area, resulting in more conclusive results. Gender characteristics, disparities in grade levels (if obtained from various levels), and different school can all be utilized as comparisons between one school and another in further research. Subsequent research suggests increasing the frequency of small group discussions so that research results are more proven, and the effects of small group discussions are clearly visible.

\section{ACKNOWLEDGEMENT}

The authors express gratitude to Dr. Wahyuningsih, M.Pd. as a lecturer in the $5^{\text {th }}$ semester writing course, who has guided and directed patiently in completing this research, as well as various parties who have provided motivation and enthusiasm in completing the research. This research was not funded by external funding sources.

\section{REFERENCES}

Arifin, W. L. (2017). Psychological Problems and Challenge In EFL Speaking Classroom. REGISTER JOURNAL, 1O(1), 29-47. http://dx.doi.org/10.18326/rgt.v10i1.29-47

Bailey, D., Almusharraf, N., \& Hatcher, R. (2021). Finding satisfaction: intrinsic motivation for synchronous and asynchronous communication in the online language learning context. Education and Information Technologies, 26(3), 2563-2583. https://doi.org/10.1007/s10639020-10369-z

Baron, P., Linquanti, R., \& Huang, M. (2020). Validating Threshold Scores for English Language Proficiency Assessment Uses. In Assessing English language proficiency in US K-12 schools (pp. 
161-184). Routledge.

Bohari, L. (2020). Improving Speaking Skills Through Small Group Discussion At Eleventh Grade Students of Sma Plus Munirul Arifin Nw Praya. Journal of Languages and Language Teaching, 7(1), 68. https://doi.org/10.33394/jollt.v7i1.1441

Daely, M., Astarini, S., \& Husnussalam, H. (2019). Improving students speaking skill using group discussion. PROJECT (Professional Journal of English Education), 2(4), 466-474.

Fitriani, Y., Bandung, M., \& Kadri, M. K. (2020). Students' Perspective of Online Learning on Speaking Class During Covid-19 Pandemic. Humanitatis: Journal of Language and Literature, $7(1), 1-12$.

Harmer, J. (2007). The practice of English language teaching with DVD (4th edition). Pearson Education Limited.

Isnaini, N. (2018). An Analysis of Students' Speaking Anxiety Students of English Foreign Language (Efl) at The Fifth Semester English Department of UIN Raden Intan Lampung Academic Year Of 2018/2019. Undergraduate Thesis. Raden Intan State Islamic University.

Johnson, A. (2020). Online Teaching With Zoom A Guide For Teaching and Learning With Videoconference Platforms. In Excellent online teaching.

Larasati, F. (2018). Student Centered Learning: an Approach To Develop Speaking Skill in Efl Classroom. English Community Journal, 2(1), 153-157. https://doi.org/10.32502/ecj.v2i1.1004

McDaniels, M., Pfund, C., \& Barnicle, K. (2016). Creating dynamic learning communities in synchronous online courses: One approach from the center for the integration of research, teaching and learning (CIRTL). Online Learning Journal, 20(1), 110-129. https://doi.org/10.24059/olj.v20i1.518

Opandi, E. F. (2019). Students' Self-Confidence on Fifth Semester Student of Jambi University When Speaking in Classroom. Undergraduate Thesis. Jambi University.

Ratih, E., Asrori, M., Sulistyawati, H. (2016). Improving Speaking Using Small Group Discussion. English Education Journal, 4(2), 169-174.

Risma, S. N. (2021). an Analysis of the Utilizing Zoom Application To English Learners' Speaking Skill Motivation. PROJECT (Professional Journal of English Education), 4(3), 433. https://doi.org/10.22460/project.v4i3.p433-445

Silaban, L. M. C. (2016). Students' attitudes toward small group discussion in the academic reading class. Undergraduate Thesis. Universitas Kristen Satya Wacana.

Suryadi, H. (2020). The Effect Of Using Small Group Discussion On The Second Grade Students' Speaking Skill. Jurnal IImu Sosial Dan Pendidikan, 4(3), 293-298. http://dx.doi.org/10.36312/jisip.v4i3.1218

Tasmia, T. (2019). Students' Problems in Speaking English at Eight Grade of Riyadhul Amien Islamic Boarding Junior High School Muaro Jambi. Undergraduate Thesis. State Islamic University of Sulthan Thaha Saifuddin Jambi.

Thornbury, S. (2005). How to Teach Speaking. Longman.

Vollbrecht, P. J., Porter-Stransky, K. A., \& Lackey-Cornelison, W. L. (2020). Lessons learned while creating an effective emergency remote learning environment for students 
during the COVID-19 pandemic. Advances in Physiology Education, 44(4), 722-725. https://doi.org/10.1152/advan.00140.2020

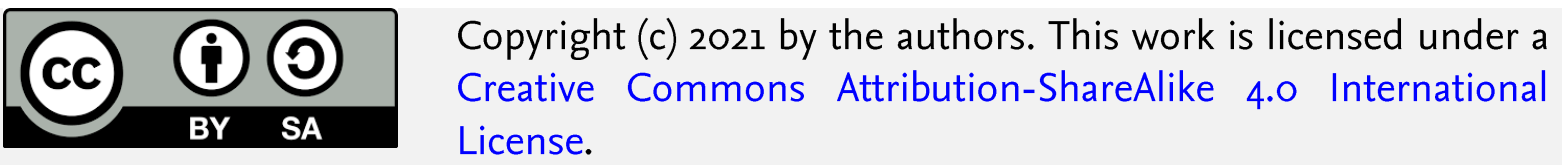

